\title{
PHOTOELECTRIC PROPERTIES OF SCREEN-PRINTED Al-DOPED ZnO FILMS
}

\author{
A. Ogurcovs, Vj. Gerbreders, E. Tamanis, \\ S. Gerbreders, G.Liberts \\ Innovative Microscopy Center, Daugavpils University, \\ 1 Parades Str., Daugavpils, LV-5401, LATVIA
}

\begin{abstract}
The potential of cheap semiconductor materials in the area of solar energy use is illustrated by the example of zinc oxide (pure and Al-doped in various concentrations). Under investigation was the electric conductivity and photoelectric properties of $\mathrm{ZnO}$ thin films. The samples were prepared using screen-printing technique. The results of measurements point to non-linear relationships between Al concentration, photosensitivity and electrical conductivity of thin $\mathrm{ZnO}$ films. Optimal $\mathrm{Al}$ concentration for practical use of $\mathrm{ZnO}$ in photovoltaic devices is found to be $\sim 1 \%$. The experimental methods, technologies and results described in the paper could be used for further investigations in this area.
\end{abstract}

Key words: Al-doped $\mathrm{ZnO}$ films, screen printing technique.

\section{INTRODUCTION}

The current world energy crisis is forcing the scientific community to search for cheaper and more efficient ways of energy production. One of them is the use of monocrystalline solar cells (COP 23\% [1]); however, their manufacturing cost is very high, and is not repaid by the electricity produced during their operation. For this reason, alternative semiconductor structures such as zinc oxide are investigated worldwide. As compared with other semiconductor materials, $\mathrm{ZnO}$ has much higher excitation energy of excitons; it is more resistant to radiation and is a multifunctional material, with piezoelectric, ferroelectric and ferromagnetic properties [2]. Zinc oxide is a semiconductor with a wide bandgap $(E=3.37 \mathrm{eV})$, and can be used in semiconductor lasers and UV-LED technologies [3]. This material is applied in solar cells, piezoelectric transducers as well as in the form of catalytic particles and sensors [4] for determination of the molecular composition of gases. Zinc oxide is also ecologically clean and biocompatible material, which is important in medical applications [5]. The main problem in the use of impurity-free $\mathrm{ZnO}$ is that this material has an immense specific resistance. This peculiarity complicates the practical application of pure zinc oxide. For electrical resistance reduction purpose, the doping of $\mathrm{ZnO}$ is applied using different chemical combinations [6]. For studying a semiconductor material of the kind the screenprinting technique has been proved to be very convenient. This technique is cheap and technologically simple. 


\section{EXPERIMENTAL}

\subsection{Preparation of the substrate}

The substrates $(25 \times 35 \mathrm{~mm}$ in size $)$ were made from ordinary glass. After ultrasonic surface cleaning, they were placed in a high-vacuum camera "УCУ-4" for sputtering a thin conducting nickel electrode. The sputtering was performed using a specially made mask shaped as a system of parallel electrodes (total nine on each substrate), with a width of $0.5 \mathrm{~mm}$ and a height of $25 \mathrm{~mm}$. The minimum distance between two electrodes was $0.5 \mathrm{~mm}$, the maximum $-4 \mathrm{~mm}$. Such location of electrodes allows different areas of thin $\mathrm{ZnO}$ film to be checked for homogeneity.

\subsection{Preparation of the mixture}

Micro-fine powder of zinc oxide was mechanically mixed with aluminium chloride to obtain $\mathrm{Al}_{2} \mathrm{O}_{3}$ doped $\mathrm{ZnO}$ powders of different weight percentage $(1,3,5$ and $7 \mathrm{wt} . \%$ ) [1]. The prepared powder was calcined at $900{ }^{\circ} \mathrm{C}$ for $5 \mathrm{~h}$ in air and ball-milled to ensure a sufficiently fine particle size. Such a long calcination time is necessary to get rid of chlorine.

\subsection{Preparation of the samples}

The doped $\mathrm{ZnO}$ was mixed with 2-phenoxyethanol $\left(\mathrm{C}_{8} \mathrm{H}_{10} \mathrm{O}_{2}\right)$ in proportion 70:30 to provide a binder of the desired viscosity. The binder was deposited on the glass substrates with electrodes using the screen-printing technique. The prepared samples were annealed at $180{ }^{\circ} \mathrm{C}$ for $1 \mathrm{~h}$ in air to evaporate 2-phenoxyethanol from the samples.

\section{RESULTS AND DISCUSSION}

\subsection{Structure and chemical composition of the thin films.}

The microstructure and chemical composition of the film surface were analyzed using a scanning electron microscope (SEM, Tescan Vega LMU) coupled with an energy dispersive spectrometer (INCA X-Ray Microanalysis). The X-ray powder diffraction analysis was performed using an X-ray diffractometer (Rigaku Smartlab).

Figure 1 shows the SEM image of Al-doped $\mathrm{ZnO}$ film. It is seen that the film contains voids and grains. Their sizes are found to range from 100 to $400 \mathrm{~nm}$.

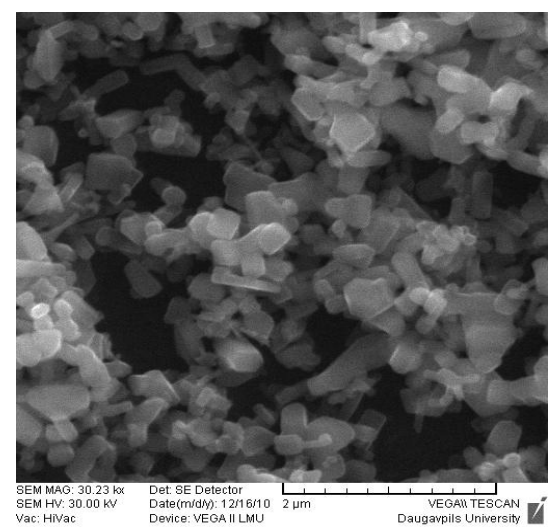

Fig. 1. The screen-printed $\mathrm{Al}(1$ wt.\%) doped $\mathrm{ZnO}$ surface. 
The quantitative elemental compositions of the pure and doped $\mathrm{ZnO}$ films were analyzed using an energy dispersive spectrometer. The mass $\%$ of $\mathrm{Al}$ in each sample was not in the stoichiometric proportion. Table 1 shows the $\mathrm{Al}$ concentration in the samples.

Table 1

The Al concentration in the samples

\begin{tabular}{|l|c|c|c|c|}
\hline Number of sample & 1 & 2 & 3 & 4 \\
\hline Measured Al concentration, \% & 0.15 & 0.45 & 0.89 & 1.18 \\
\hline
\end{tabular}

The crystalline structure and chemical composition of the films were analyzed by means of an X-ray diffractometer (Rigaku Smartlab) using CuKó $1.544 \AA$ emission. Figure 2 depicts an XRD pattern of non-modified (pure) and Aldoped $\mathrm{ZnO}$ films. The peaks seen in Fig. $1 a$ are matching well with the PDXL database reported data on $\mathrm{ZnO}$ [7]. The peaks of XRD pattern in Fig. $1 b$ correspond to the $\mathrm{ZnO}, \mathrm{ZnAl}_{2} \mathrm{O}_{4}$ materials, which are considered to be microcrystalline in nature. The peaks of $\mathrm{ZnO}$ and $\mathrm{ZnAl}_{2} \mathrm{O}_{4}$ are designated by $\mathrm{X}$ and $\mathrm{Y}$.
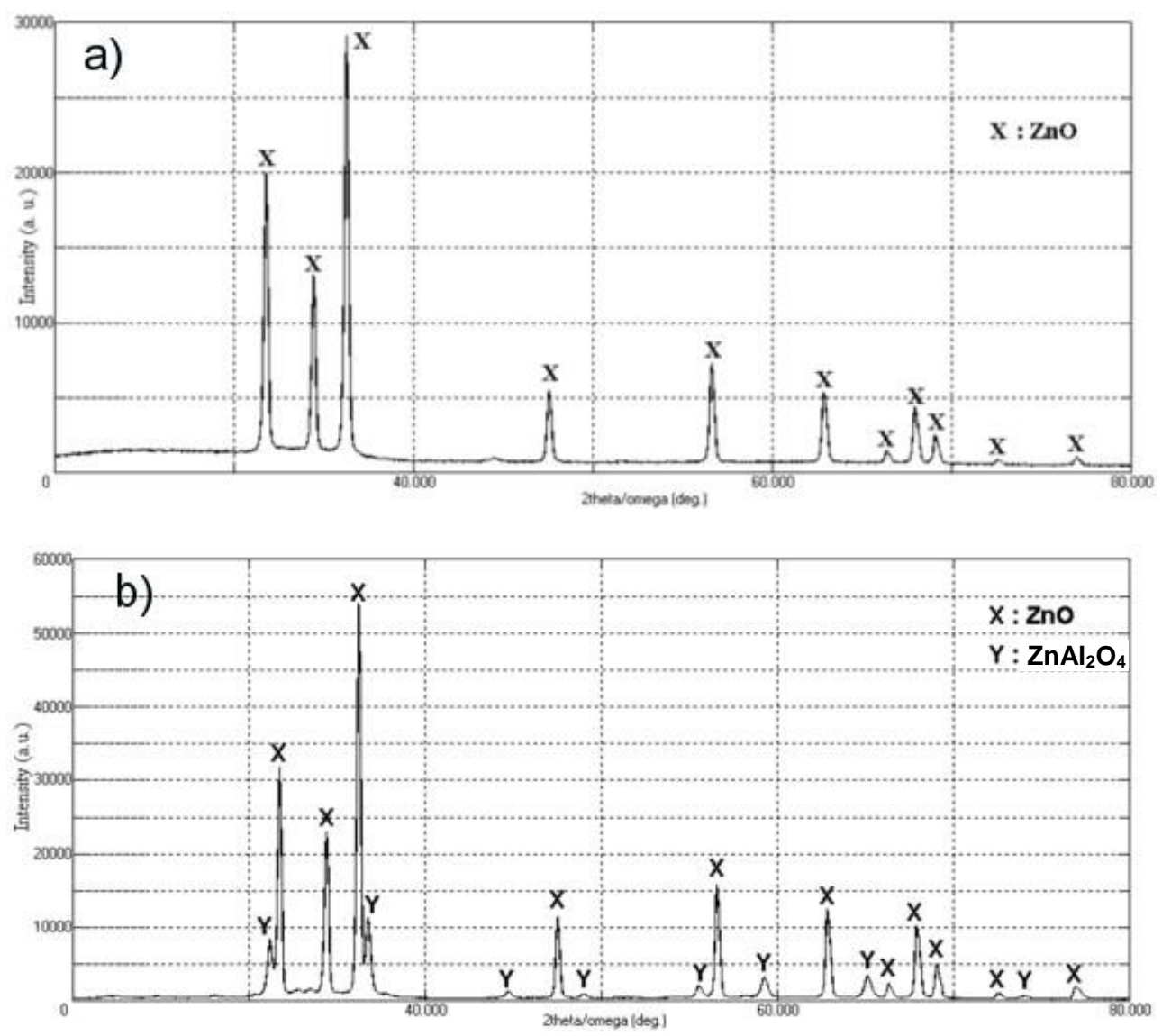

Fig. 2. XRD of (a) non-modified $\mathrm{ZnO}$ and

(b) Al-doped (0.89 wt.\%) $\mathrm{ZnO}$. 


\subsection{Photoelectric properties of thin films.}

Photoelectric parameters of pure and $\mathrm{Al}$-doped $\mathrm{ZnO}$ films were measured by the device consisting of a $405 \mathrm{~nm}$ laser source, a laser power meter (Ophir Nova II), a multimeter (Picotest M3500A), a laptop and the optical system. Measurements of electric resistance were performed at a constant laser beam power. For preparation of samples the areas $3 \mathrm{~mm} \times 3 \mathrm{~mm}$ in size were deposited at the $0.2 \mathrm{~W} / \mathrm{cm}^{2}$ laser beam intensity. The corresponding group of nickel electrodes on the glass substrate were connected to the multimeter in the resistance measurement mode. The duration of data reading was $0.5 \mathrm{~s}$. The full measurement cycle for each sample took $210 \mathrm{~s}$. Figure 3 shows the electric resistance variations for the pure and Al-doped (0.15 wt.\%) $\mathrm{ZnO}$ samples. In the figure, domain 1-2 corresponds to the start-end of measurements, domain 2-3 - to the saturation of electric resistance under laser deposition, and domain 3-4 - to its relaxation after deposition. In the case of pure $\mathrm{ZnO}$ the initial electric resistance steeply decreases from $\mathrm{R}_{\text {init }}=$ $1.1 \times 10^{8} \mathrm{Ohm}$ to $\mathrm{R}_{\min }=0.45 \times 10^{6} \mathrm{Ohm}$ within $1 \mathrm{~s}$. After the end of deposition, the electric resistance restores to its initial level in $1 \mathrm{~s}$. As seen in the figure, much lower initial electric resistance $\mathrm{R}_{\text {init }}=5 \times 10^{7} \mathrm{Ohm}$ and longer relaxation time are observed for the $0.15 \% \mathrm{Al}$ doped $\mathrm{ZnO}$ in comparison with the pure $\mathrm{ZnO}$ sample.

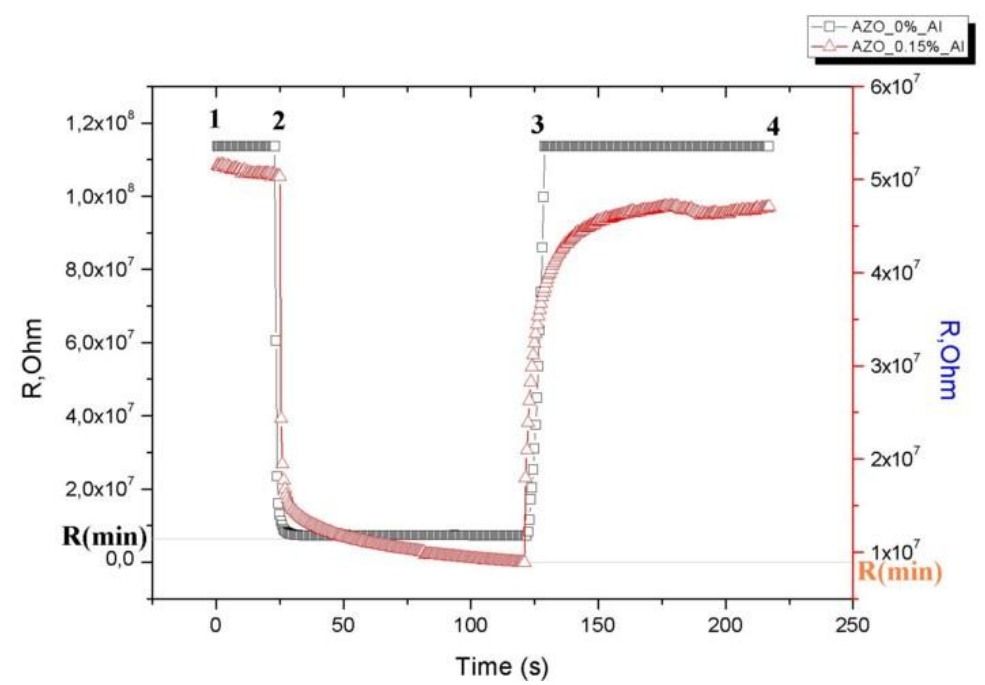

Fig. 3. Variations in the electric resistance of pure and $0.15 \%$ Al-doped $\mathrm{ZnO}$ samples in a full cycle of deposition-relaxation.

Significant increase in the relaxation time of electric resistance is observed for $0.89 \% \mathrm{Al}$ doped $\mathrm{ZnO}$ sample (see Fig. 4, domain 3-4).

Figure 5 shows the comparative relaxation time of electric resistance for pure and Al-doped $\mathrm{ZnO}$ films. The curves describe a relative variation in the electric resistance, $R_{1} / R_{0}$ and $R_{2} / R_{0}\left(R_{0}\right.$ being the resistance of samples before deposition, $R_{1}$ and $R_{2}-$ after 150 and 200 s relaxation). Laser deposition was stopped at the $120^{\text {th }}$ second of the experiment.

In Fig. 5 it is seen that at $\mathrm{Al} \%<1$ the relaxation time of electric resistance is much greater than the time of its saturation under $405 \mathrm{~nm}$ laser deposition; vice versa, if $\mathrm{Al}$ concentration exceeds $1 \%$ the time of saturation is much longer than 
that of relaxation. With increasing $\mathrm{Al}$ concentration the dark (initial) resistance of samples decreases proportionally. At $\mathrm{Al} \%>1.5 \%$ a very low dark resistance is observed but the samples are practically insensitive to the $405 \mathrm{~nm}$ laser radiation. It could be suggested that the $\mathrm{Al}$ atoms cause an increase in the total concentration of free charge carriers and in the lifetime of photoinduced charge carriers in $\mathrm{ZnO}$.

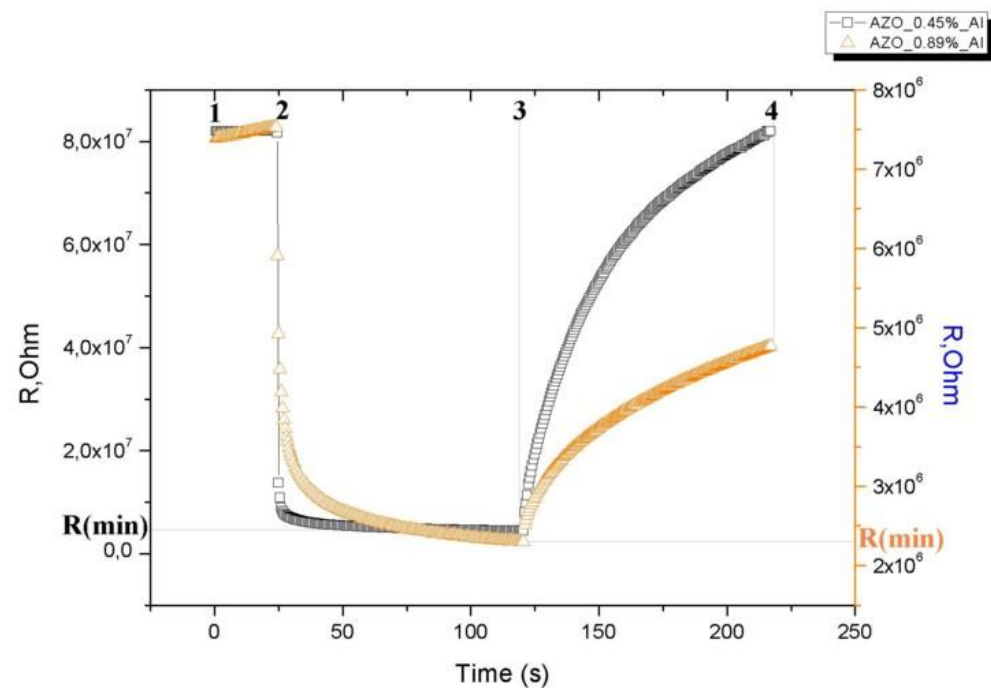

Fig. 4. Variations in the electric resistance of $0.45 \%$ and $0.89 \%$ Al-doped $\mathrm{ZnO}$ samples in a full cycle of deposition-relaxation.

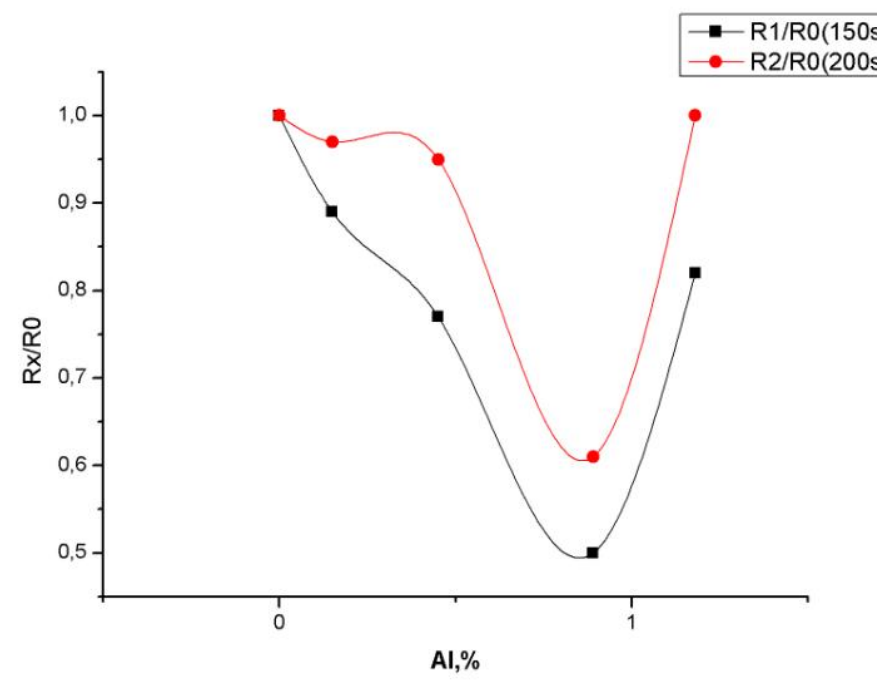

Fig.5. Relative variation in the electric resistance of $\mathrm{ZnO}$ thin-film samples $v s$.Al dopant concentration.

\section{CONCLUSIONS}

The study of Al-doped screen-printed $\mathrm{ZnO}$ thin films has made it possible to determine their photosensitivity and to reveal the total conductivity of the samples is increasing with $\mathrm{Al}$ concentration. The experiments have shown that the best ratio between the conductivity and the photosensitivity is achieved with $1 \% \mathrm{Al}$ concen- 
tration. This result could be considered of the key significance for raising the efficiency of $\mathrm{ZnO}$-based photosensitive semiconductor devices.

\section{REFERENCES}

1. Martin, A. Green, Keith Emery, Yoshihiro Hishikawa \&, Wilhelm Warta, (2009). Solar Cell Efficiency Tables (Version 33). Prog. Photovolt.: Res. Appl., 17, 85-94.

2. Nagare, B.J, Sajeev Chacko \& Kanhere, D. G. (2010) Ferromagnetism in carbon doped zinc oxide systems. J. Phys. Chem. A., 114 (7), 2689-2696. DOI: 10.1021/jp910594m.

3. Huihui Huang, Guojia Fang, Xiaoming Mo, Hao Long, Longyan Yuan, Binzhong Dong, Xianquan Meng, \& Xingzhong Zhao. (2009). ZnO-based fairly pure ultraviolet light-emitting diodes with a low operation voltage. Electron. Device Letters, 30 (10), 1063-1065.

4. Patil, D.R., Patil, L.A., \& Amalnerkar, D.P. (Dec. 2007). Ethanol gas sensing properties of $\mathrm{Al}_{2} \mathrm{O}_{3}$-doped $\mathrm{ZnO}$ thick film resistors. Bull. Mat. Sci., 30 (6), 553-559.

5. Gopikrishnan, R.,. Pradhan Zhang, K., Ravichandran, P., Baluchamy, S., Ramesh, V., Biradar, S., Ramesh, P., Hall, J.J.C., Pradhan, A.K., \& Ramesh, G.T. (2010). Synthesis, characterization and biocompatibility studies of zinc oxide $(\mathrm{ZnO})$ nanorods for biomedical application. Nano-Micro Letters, 2 (1) 31-36.

6. Bindu Krishnan \& Nampoori V P N (June 2005). Screen printed nanosized ZnO thick film. Bull. Mater. Sci., 28 (3), 39-242.

7. PDXL Software. Version 1.8.1.0 Copyright 2007-2011 Rigaku Corporation.

\section{AR SIETSPIEDES DRUKAS IEGŪTO Al ZnO KĀRTIN̦U FOTOELEKTRISKĀS ĪPAŠİBAS}

\section{A. Ogurcovs, Vj. Gerbreders, E. Tamanis, S. Gerbreders}

$$
\text { Kopsavilkums }
$$

Galvenais uzsvars ir likts uz cinka oksīda elektriskās vadāmības un gaismjutības regulēšanu legeēšanas ceḷā, kā arī plānu kārtinu iegūšanas vienkāršošanu, izmantojot sietspiedes drukas tehnologiju. Autoru aprakstītās eksperimentālās metodes un tehnoloǵijas sniedz plašu darbības lauku tālākiem pētījumiem šajā jomā.

14.03. 2012. 